\title{
SETX Gene
}

National Cancer Institute

\section{Source}

National Cancer Institute. SETX Gene. NCI Thesaurus. Code C124949.

This gene is involved in DNA and RNA metabolism 